\title{
A new variety of Plocama calabrica (Rubiaceae) from Denizli (Turkey) confirmed by morphological and molecular ISSR markers
}

\author{
Ramazan Süleyman Göktürk ${ }^{1}$, Olcay Düşen ${ }^{2 *}$, Ergun Kaya ${ }^{3}$, Betül Gürcan², Uygar Sarpkaya ${ }^{2}$ \\ ${ }^{1}$ Akdeniz University, Faculty of Science, Department of Biology, 07058 Antalya, Turkey. \\ ${ }^{2}$ Pamukkale University, Faculty of Arts and Science, Department of Biology, 20160, Kinikli, Denizli, Turkey. \\ ${ }^{3}$ Muğla Sıtkı Koçman University, Faculty of Science, Molecular Biology and Genetic Department, 48000, Kötekli, Muğla, \\ Turkey.
}

\begin{abstract}
Plocama calabrica (L.f.) M.Backlund \& Thulin var. alba Göktürk, O.D.Düşen, B.Gürcan \& U. Sarpkaya variety nova is described from South-West Anatolia. The new variety grows on limestone slopes between Akpınar and Yaylapınar villages in the Çameli district in Denizli. It is closely related to P. calabrica var. calabrica, and can be readily distinguished by morphological and molecular characters from the related variety. Taxonomic comments such as descriptive and diagnostic characters, distribution and ecology, phenology and proposed conservation status for this new variety are given in the current study. Morphological affinities and the inter-simple-sequence repeat (ISSR)-PCR based phylogenetic relationships between the new and the related variety are also discussed
\end{abstract}

Keywords: ISSR-PCR, molecular marker, new variety, Plocama, systematics, Turkey

\section{Introduction}

The family Rubiaceae comprises 650 genera and $c a$. 11000 species, distributed throughout almost all the regions of the world, although they are found mainly in tropical and subtropical regions (Ortiz et al. 2000). Putoria is a monotypic genus which belongs to Rubiacaeae in Turkey, and was revised by Ehrendorfer in the Flora of Turkey and the East Aegean Islands (Ehrendorfer 1982). The genus of Putoria was treated as a synonym of Plocama genus by Backlund et al. 2007. Plocama was represented by 34 species and 1 subspecies until 2009 (Backlund et al. 2007, IPNI 2015). Since then, one new species has been described from Uzbekistan (Khassanov et al. 2014). With the description here of P. calabrica var. alba there are now two taxa in Turkey and worldwide there are in all 37 Plocama taxa. In the flora of Turkey, the genus Plocama is represented only by P. calabrica (L. fil) DC. P. calabrica is known from Spain, Italy (incl. Sicily), Malta, Montenegro, Bosnia and Herzegovina, Croatia, Albania, Greece (incl. Crete), Cyprus, Turkey, Israel, Lebanon, Iraq, Syria, Morocco, Algeria, Tunisia, and Libya (Backlund and Thulin 2007).
True and rapid determination of degrees of genetic relationship and genetic diversity levels are required for conservation and/or utilization of plant breeding programs. During the last twenty years, usage of DNA-based molecular marker systems has increased faster than chemical or other morphological characterization systems (Collard et al. 2005, Bernardo 2008). Formerly, these markers were quite expensive and laborious, but technological improvements have made them cheaper, faster and relatively easy (Yang et al. 2015). The inter-simple-sequence repeat (ISSR) marker system is based on amplification of DNA fragments using a single microsatellite sequence primer designed with six trinucleotide or eight dinucleotide repeats and one more anchor nucleotide (Zietkiewicz et al. 1994). This marker technique has been verified as a simple, fast and low-cost way to determine genetic diversity (Sarla et al. 2003), to investigate relationships between cultivars (Martins et al. 2003, Kaya 2015), to use evolutionary studies such as gene flow (Wolfe et al. 1998), and to detect genetic stability (Kaya et al. 2017). The practicality and utility of ISSR primers has been evalu-

* Corresponding author e-mail: odusen@pau.edu.tr 
ated in this work for identifying the differences between two taxa of Plocama calabrica.

\section{Materials and methods}

\section{Morphological study}

In June 2017, during a project named "Biodiversity and Monitoring studies of Terrestrial and Inland Water Ecosystems in Denizli Province", the authors collected some interesting Plocama specimens (Fig. 1,2). While the normal color of $P$. calabrica var. calabrica individuals is pink, individuals of this new variety were interesting because of their white flowers. In total, 10 herbarium specimens of the new variety were collected from the type locality. Plocama specimens were dried for morphological and molecular phylogenetic studies according to standard herbarium techniques and preserved in the Pamukkale University Herbarium (PAMUH). After drying process, these specimens were checked using the basic floras, Flora of Turkey (Ehrendorfer 1982), Flora Europaea (Ball 1976), Flora Italiana (Tanfani 1887) and related papers (Backlund et al. 2007, Backlund and Thulin 2007, Karabacak 2012) and also confirmed by comparison with the e-herbarium samples in the B, BGBM, C, BR, E, M, $\mathrm{P}, \mathrm{SAV}, \mathrm{W}$ and WU herbaria. After detailed morphological and molecular phylogenetic studies, we decided that $P$. calabrica var. alba was a variety new to science.

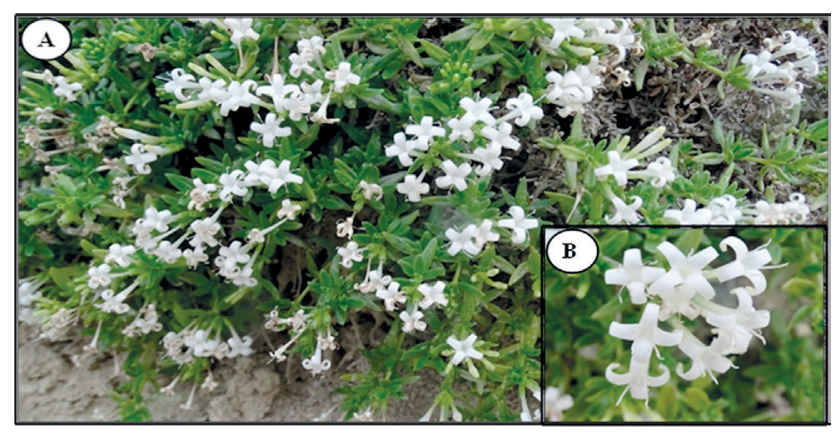

Fig. 1. A general view of Plocama calabrica var. alba in nature (A) with detail of flowers (B).

\section{Molecular phylogenetic study}

Genomic DNA was isolated from three individual plants of two different characteristic taxa belonging to dry P. calabrica herbarium samples using a modified protocol developed by Ferdous et al. (2012). The method based on cetyltrimethylammonium bromide (CTAB) extraction included one more step, the use of chloroform:isoamyl alcohol:phenol (24:1:5, v/v). Polymerase chain reactions were carried out using $40 \mathrm{ng} \mathrm{ul}^{-1}$ DNA template, $1 \times$ PCR buffer, $2.5 \mathrm{mM} \mathrm{MgCl}_{2}, 0.4 \mathrm{mM}$ dNTP, 1 unit Taq DNA polymerase and ten ISSR primers (Tab. 1) in a $25 \mu \mathrm{L}$ reaction mix (Martins-Lopes et al. 2009, Ozudogru et al. 2011, Smykal et al. 2011, Düşen et al. 2018). DNA band profiles were amplified at $95^{\circ} \mathrm{C}$ for $3 \mathrm{~min}$ initial denaturation followed by 35 reaction cycles $\left(95^{\circ} \mathrm{C} 15 \mathrm{~s} ; 55^{\circ} \mathrm{C} 30 \mathrm{~s} ; 72{ }^{\circ} \mathrm{C}\right.$ $3 \mathrm{~min}$ ) and finally extended with $72^{\circ} \mathrm{C} 10 \mathrm{~min}$. PCR prod-
Tab. 1. ISSR primer sequences and GenBank accessions numbers (Martins-Lopes et al. 2009, Smykal et al. 2011) used in molecular phylogenetic analysis of Plocama calabrica var. calabrica and P. calabrica var. alba.

\begin{tabular}{ccc}
\hline Primer & Sequence & $\begin{array}{c}\text { GenBank } \\
\text { accesion number }\end{array}$ \\
\hline ISSR1 & $(\mathrm{AG})_{8} \mathrm{~T}$ & UBC 807 \\
ISSR2 & $(\mathrm{AG})_{8} \mathrm{G}$ & $\mathrm{UBC} 809$ \\
ISSR3 & $(\mathrm{GA})_{8} \mathrm{~T}$ & $\mathrm{UBC} 810$ \\
ISSR4 & $(\mathrm{GA})_{8} \mathrm{C}$ & $\mathrm{UBC} 811$ \\
ISSR5 & $(\mathrm{CA})_{8} \mathrm{~A}$ & $\mathrm{UBC} 817$ \\
ISSR6 & $(\mathrm{TC})_{8} \mathrm{C}$ & $\mathrm{UBC} 823$ \\
\hline
\end{tabular}

ucts were separated on $1.5 \%$ agarose gel and visualized under UV light after being stained with ethidium bromide. PCR band profiles were recorded as 1 (present) or 0 (absent) and cluster analysis was performed to construct dendrograms, with the unweighted pair-group method by arithmetic averages (UPGMA) from the similarity data matrices using Jaccard's coefficient (D-UPGMA, 2002).

\section{Results}

\section{Taxonomy}

Plocama calabrica (L.f.) M. Backlund \& Thulin var. alba Göktürk, O. D. Düşen, B. Gürcan \& U. Sarpkaya var. nov. (Figs. 1, 3)

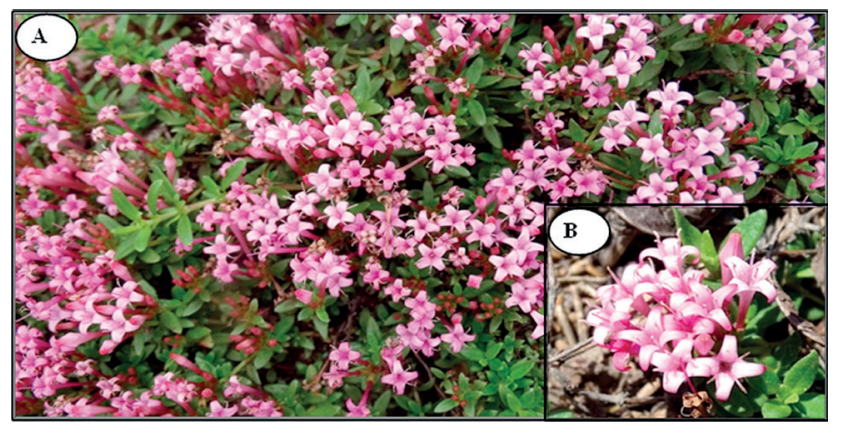

Fig. 2. A general view of Plocama calabrica var. calabrica in nature (A) with detail of flowers (B).

Holotype:-TURKEY. C2 Denizli: Çameli, between Akpınar and Yaylapınar villages, limestone slopes, $1166 \mathrm{~m}$, 21 June 2017, O. D. Düşen (2584) \& R. S. Göktürk (holotype PAMUH!, isotypes Akdeniz Univ. Herb.!).

Procumbent shrubs. Stem much branched, woody at base, $5-25 \mathrm{~cm}$, forming mats up to $1.5 \mathrm{~m}$ in diameter, puberulent. Leaves opposite, $10-15(-20) \times 2-3.5(-4.5) \mathrm{mm}$, lanceolate to oblong, obtuse, narrowed into a short petiole, revolute, slightly scabrid on margins and midrib, somewhat leathery-succulent, blackening when dry; stipules small, linear-oblong, \pm fused. Flowers grouped in laxly contracted shortly pedicellate cymes, hermaphrodite, 4 -merous. Calyx greenish, tubular, persistent and inflated in fruit; teeth 4 , greenish, unequal triangular. Corolla infundibular with a long tube, 8-15 (-20) $\mathrm{mm}$, white, glabrous outside, hairy 
inside; lobe 4, valvate. Stamen 4, inserted at corolla throat; anther white, dorso-basifixed, exserted; filament white. Style white, filiform, with very short bifid stigma. Ovary bilocular, each cell with one basal ovule. Fruit drupe, 4-6 mm, oblong, with two pyrenes, glossy.

Plocama calabrica includes 2 varieties and the diagnostic keys are presented below;

Calyx teeth reddish; corolla pink; anther and filament pink var. calabrica

Calyx teeth greenish; corolla white; anther and filament white. var. alba

The new variety is different from $P$. calabrica var. calabrica (Figs. 1,2) and the two are compared on the basis of morphological characters in Tab. 2.

Tab. 2. Morphological comparison of Plocama calabrica var. calabrica and P. calabrica var. alba flowers.

\begin{tabular}{ccc}
\hline Characters & $\begin{array}{c}\text { Plocama calabrica } \\
\text { var. calabrica }\end{array}$ & $\begin{array}{c}\text { Plocama calabrica } \\
\text { var. alba }\end{array}$ \\
\hline Cymes in flowering & densely contracted & laxly contracted \\
Calyx teeth & reddish & greenish \\
Corolla & pink & white \\
Anther & pink & white \\
Filament & pink & white \\
Style & pink & white \\
\hline
\end{tabular}

\section{Distribution and ecology}

This variety is endemic to South-West Anatolia, Turkey (Fig. 3). It grows on limestone slopes at an elevation of 1166 $\mathrm{m}$ (Fig. 4). It is associated with some plants such as Plocama calabrica (L.f.) M. Backlund \& Thulin var. calabrica (Fig. 2), Dianthus zonatus Fenzl var. zonatus, Pinus brutia Ten var. brutia, Tussilago farfara L. and Glaucosciadium cordifolium (Boiss.) B. L. Burtt \& P. H. Davis.

Phenology: flowering time is May to June. Fruiting time is July to August.

Proposed conservation status: Plocama calabrica var. alba is known only from one restricted locality. It is suggest- ed that this new variety should be placed under the IUCN threat category "Critically Endangered (CR)" (IUCN 2012), because the estimated area of occupancy is less than $10 \mathrm{~km}^{2}$ (criterion B2) and it is known only from one locality (criterion $\mathrm{B} 2 \mathrm{a}$ ). The population size of the new species is estimated to be less than 50 mature individuals (criterion C2-ai). In addition, the distribution area of the new taxon may be destroyed by anthropogenic effects such as road construction or grazing in the near future.

Etymology: the specific epithet is derived from corolla, anther and filament color.

Specimens examined of Plocama calabrica var. calabrica: TURKEY. C3 Antalya: Çakırlar, south of Çakırlar, roadside, 25 m, 13 August 1993, R. S. Göktürk (3080) (Akdeniz Univ. Herb.!). C3 Antalya: Saklıkent, Pinus clearings, 1600 m, 8 July 1995, O.Dinç (1087) (Akdeniz Univ. Herb.!)). C2 Denizli: Kocabaş, limestone slopes, 604 m, 21 May 2017, O.D.Düşen (1871) \& R. S. Göktürk (PAMUH!). C2 Denizli: Çakıroluk, Pinus clearings, 1172 m, 20 June 2017, O.D.Düşen (2391) \& R. S. Göktürk (PAMUH!). C2 Denizli: Çameli, between Akpınar and Yaylapınar villages, limestone slopes, 1166 m, 21 June 2017, O.D.Düşen (2583) \& R. S. Göktürk (PAMUH!). C2 Denizli: Çamlık, roadside, 815 m, 8 June 2018, O.D.Düşen (5170) \& R. S. Göktürk (PAMUH!).

\section{Molecular phylogenetic data}

Leaf samples belonging to six individuals from $P$. calabrica var. calabrica and $P$. calabrica var. alba (three individuals from each) were analyzed using six ISSR primers to prove that they are separate varieties. The total 35 reproducible bands ranging 565 to 2010 bp were obtained from PCR reactions using ISSR1, 5 and 6 primers (Tab. 3). The polymorphism rate was calculated as $68.6 \%$ between the two taxa and the genetic differences were able clearly to be seen from stained band profiles on agarose gel (Fig. 5).

The similarity matrix values, ranging up to 0.462 , generated by Jaccard's coefficient method showed considerable distinction between two taxa and dendogram analyses divided them into two main clusters. The results obtained by molecular fingerprinting and by morphological analyses were

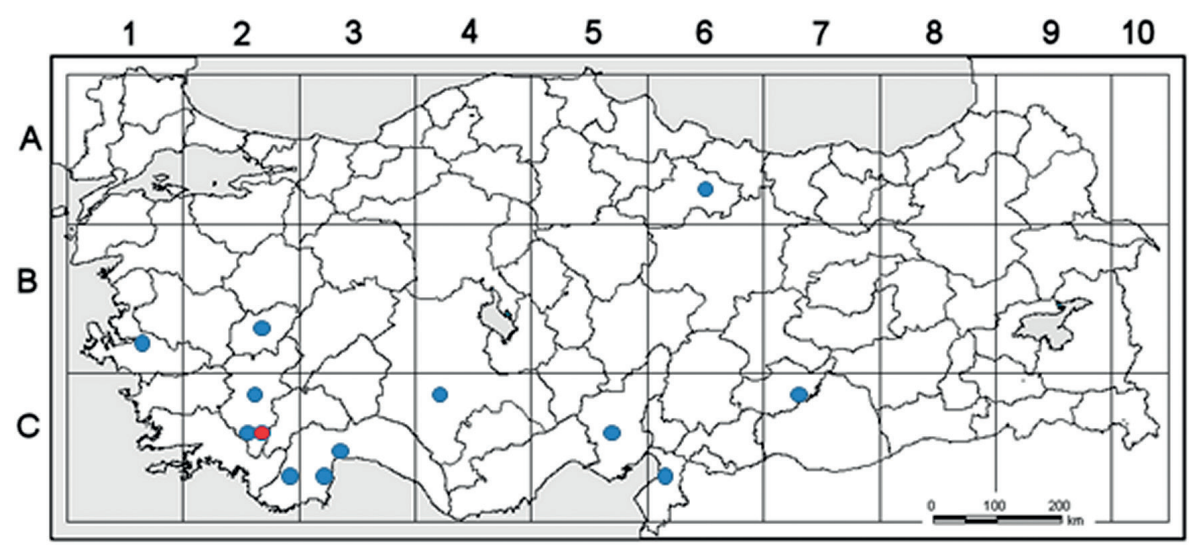

Fig. 3. Distribution of Plocama calabrica var. calabrica (blue dots) and P. calabrica var. alba (red dot) in Turkey. 
Tab. 3. Analysis of band profiles obtained from PCR reactions with six samples belonging to three individuals of Plocama calabrica var. calabrica and P. calabrica var. alba using three productive primers.

\begin{tabular}{|c|c|c|c|c|c|c|}
\hline Primer & Total bands & $\begin{array}{c}\text { The biggest } \\
\text { band size (bp) }\end{array}$ & $\begin{array}{l}\text { The smallest } \\
\text { band size (bp) }\end{array}$ & $\begin{array}{c}\text { The total polymorphic } \\
\text { bands }\end{array}$ & $\begin{array}{l}\text { The total monomorphic } \\
\text { bands }\end{array}$ & $\begin{array}{c}\text { Polymorphism } \\
(\%)\end{array}$ \\
\hline ISSR 1 & 13 & 1950 & 570 & 9 & 4 & 69.2 \\
\hline ISSR 5 & 11 & 1700 & 565 & 7 & 4 & 63.6 \\
\hline ISSR 6 & 11 & 2010 & 565 & 8 & 3 & 72.7 \\
\hline TOTAL & 35 & 2010 & 565 & 24 & 11 & 68.6 \\
\hline
\end{tabular}

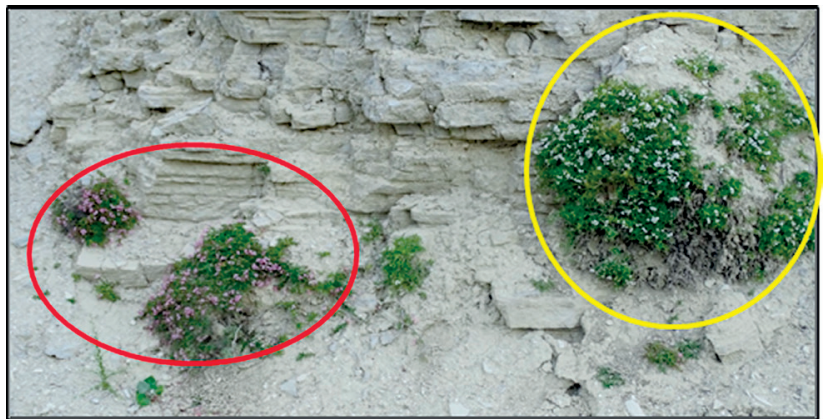

Fig. 4. Habitat of Plocama calabrica var. calabrica (red cycle) and $P$. calabrica var. alba (yellow cycle) in limestone slopes.

complementary and strongly confirmed the classification of $P$. calabrica var. calabrica and $P$. calabrica var. alba taxa into two different varieties.

\section{Discussion}

Systematic botany is based on the plant morphological characteristics that provide the major information for identification between taxa and these characteristics are obtained from morphological, physiological and anatomical features of plant tissues, organs, seeds, embryos and pollens. On the other hand, use of these features as taxonomic information source these days has been overtaken by the use of molecular markers to obtain DNA-based data, because these data provide a universal standard for the taxonomical comparison of all organisms. DNA-based systematic information has been provided by many kind of molecular marker systems such as PCR based approaches (Badr 2008).

In this study, two P. calabrica taxa that have morphological differences such as different colour flowers and especially different colour of characteristic petal margins were verified using the PCR based marker system, ISSR, to classify into a new variety. These morphological differences were strongly supported by the ISSR marker system for two $P$. calabrica taxa.

According to the results of PCR reaction analyses, it is highly probable that these two taxa belonging to $P$. calabrica may be different varieties. There are many studies carried out using a combination of both morphological and molec-

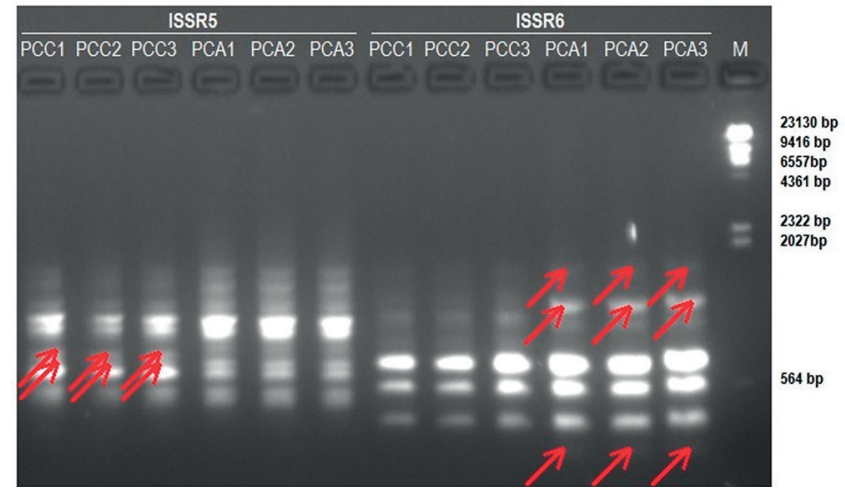

Fig. 5. PCR band profiles produced from six samples belonging to three individuals of Plocama calabrica var. calabrica (PCC1-3) and P. calabrica var. alba (PCA1-3) using ISSR5 and ISSR6 primers. $\mathrm{M}$ - marker Lambda DNA/HindIII. Arrows indicate polymorphic band profiles.

ular characteristics on different plant species. For example, Prasad (2014) obtained a polymorphism rate of $71.2 \%$ between nine different variety of Hibiscus rosa-sinensis Linn. using random amplified polymorphic DNA (RAPD) analyses. Another, similar, study was performed to determine the polymorphism rate between Secale cereale L. subspecies using RAPD and amplified fragment length polymorphisms (AFLP) analyses by Ćwiklińska and his colleagues (2010) and they obtained an up to $79 \%$ polymorphism rate.

Results of previous studies based on molecular analyses, similarly to our study, have demonstrated that polymorphism rate of taxa belonging to different plant species are consistent. For example, the polymorphism rate can be up to $90 \%$ or more for species, up to $80 \%$ for subspecies and up to $72 \%$ for varieties. Fourteen species belonging to the Coffea genus were compared using ISSR primers and 96.5\% polymorphism rate was obtained between them (Ruas et al. 2003). In another study, microsatellite markers were used for the evaluation of genetic diversity in Oryza sativa L. subspecies and an approximately $79 \%$ polymorphism rate was obtained (Junjian et al. 2002). Ko and his colleagues (1994) used RAPD primers for determination of Oryza sativa L. varieties and they obtained $67 \%$ polymorphism. Like previous studies, the current study also showed that molecular markers strongly supported the morphological differences between two different taxa of P. calabrica. The data obtained from analysis of band profiles derived from PCR reactions have been enough for it to be classified into a new variety of $P$. calabrica. 


\section{Acknowledgement}

This work was supported by the Ministry of Forestry and Water Affairs and the General Directorate of Nature
Conservation and National Parks (the project "Biodiversity and monitoring studies of terrestrial and inland water ecosystems in Denizli Province").

\section{References}

Backlund, M., Bremer, B., Thulin, M., 2007: Paraphyly of Paederieae, recognition of Putorieae and expansion of Plocama (RubiaceaeRubioideae). Taxon 56, 315-328.

Backlund, M., Thulin, M., 2007: Revision of the Mediterranean species of Plocama (Rubiaceae). Taxon 56, 516-520.

Badr, A., 2008: Molecular approaches in plant systematics and evolution. Taeckholmia 28, 127-167.

Ball, P.W., 1976: Putoria Pers. In: Tutin, T.G., Heywood, V.H., Burges, N.A., Moore, D.M., Valentine, D.H., Walters, S.M., Webb, D.A. (eds.), Flora Europaea, vol. 4., 3. University Press, Cambridge.

Bernardo, R., 2008: Molecular markers and selection for complex traits in plants: learning from the last 20 years. Crop Science 48, 1649-1664.

Collard, B.C.Y., Jahufer, M.Z.Z., Brouwer, J.B., Pang. E.C.K., 2005: An introduction to markers, quantitative trait loci (QTL) mapping and marker-assisted selection for crop improvement: the basic concepts. Euphytica 142, 169-196.

Ćwiklińska, A., Broda Z., Bocianowski, J., Dobrzycka, A., 2010: The usefulness of RAPD and AFLP markers for determining genetic similarity in rye (Secale L.) species and subspecies. Acta Biologica Cracoviensia Series Botanica 52, 19-25.

Düşen, O., Göktürk, R.S., Kaya, E., Sarpkaya, U., Gürcan, B., 2018: Morphological and molecular determination of a new Viola species (Violaceae) from Turkey. Phytotaxa 369, 37-46.

Ehrendorfer, F., 1982: Putoria Pers. In: Davis, P.H. (Ed.) Flora of Turkey and the East Aegean Islands, vol. 7, 723-724. University Press, Edinburgh.

Ferdous, J., Hanafi, M.M., Rafii, M.Y., Kharidah, M., 2012: A quick DNA extraction protocol: without liquid nitrogen in ambient temperature. African Journal of Biotechnology 11, 6956-6964.

IUCN 2012: IUCN red list categories and criteria, version 3.1, 2. ed. Gland, Switzerland and Cambridge (U.K.), 32.

IPNI 2015: The International Plant Names Index. Retrieved June 23, 2018 http://www.ipni.org .

Junjian, N., Peter, M.C., Mackil, D.J., 2002: Evaluation of genetic diversity in rice subspecies using microsatellite markers. Crop Science 42, 601-607.

Karabacak, E., 2012: Plocama. In: Güner, A., Aslan, S., Ekim, T., Vural, M., Babaç, M.T. (eds.). Turkey Plant List (Vascular Plants), 832. Nezahat Gökyiğit Botanic Garden and Flora Research Association Press, Istanbul.

Kaya, E., 2015: ISSR Analysis for Determination of genetic diversity and relationship in some Turkish olive (Olea europaea L) Cultivars. Notulae Botanicae Horti Agrobotanici Cluj-Napoca 43, 96-99.

Kaya, E., Souza, F.V.D., 2017: Comparison of two PVS2-based procedures for cryopreservation of commercial sugarcane (Saccharum spp.) germplasm and confirmation of genetic stability after cryopreservation using ISSR markers. In Vitro Cellular and Developmental Biology - Plant 53, 410-417.
Khassanov, F.O., Khamraeva, D.T., Khuzhanazarov, U., Achilova, N., 2014: A new species from genus Plocama L. (Rubiaceae Juss.) from Middle Asia. Stapfia 101, 23-26.

Ko, H.L., Cowan, D.C., Henry, R.J., Graham, G.C., Blakeney, A.B., Lewin, L.G., 1994: Random amplified polymorphic DNA analysis of Australian rice (Oryza sativa L.) varieties. Euphytica 80, 179-189.

Martins-Lopes, P., Gomes, S., Lima-Brito, J., Lopes, J., Guedes-Pinto, H., 2009: Assessment of clonal genetic variability in Olea europaea L. 'Cobrançosa' by molecular markers. Scientia Horticulturae 123, 82-89.

Martins, M., Tenreiro, R., Oliveira, M.M., 2003: Genetic related ness of Portuguese almond cultivars assessed by RAPD and ISSR markers. Plant Cell Reports 22, 71-78.

Ortiz, P.L., Arista, M., Talavera, S., 2000: Pollination and breeding system of Putoria calabrica (Rubiaceae), a mediterranean dwarf shrub. Plant Biology 2, 325-330.

Ozudogru, E.A., Kaya, E., Kirdok, E., Issever-Ozturk, S., 2011: In vitro propagation from young and mature explants of thyme (Thymus vulgaris and T. longicaulis) resulting in genetically stable shoots. In Vitro Cellular and Developmental Biology-Plant 47, 309-320.

Prasad, M.P., 2014: Molecular characterization and genetic diversity determination of Hibiscus species using RAPD molecular markers. Asian Journal of Plant Science and Research 4, 50-56.

Ruas, P.M., Ruas, C.F., Rampim, L., Carvalho, V.P., Ruas, E.A., Sera, T., 2003: Genetic relationship in Coffea species and parentage determination of interspecific hybrids using ISSR (Inter- Simple Sequence Repeat) markers. Genetics Molecular Biology 26, 410-417.

Sarla, N., Bobba, S., Siddiq, E.A., 2003: ISSR and SSR markers based on AG and GA repeats delineate geographically diverse Oryza nivara accessions and reveal rare alleles. Current Science 84, 683-690.

Smykal, P., Bacova-Kerteszova, N., Kalendar, R., Corander, J., Schulman, A.H., Pavelek, M., 2011: Genetic diversity of cultivated flax (Linum usitatissimum L.) germplasm assessed by retrotransposon-based markers. Theoretical and Applied Genetics 122, 1385-1397.

Tanfani, E., 1887: Flora Italiana, vol. 7, 101. Firenze.

Wolfe, A., Xiang, Q., Kephart, S., Xiang, Q., 1998: Assessing hybrid ization in natural populations of Penstemon (Scrophulariaceae) using hypervariable intersimple sequence repeat (ISSR) bands. Molecular Ecology 7, 1107-1125.

Yang, H.B., Kang, W.H., Nahm, S.H., Kang, B.C., 2015, Methods for developing molecular markers. In: Koh, H.J., Kwon, S.Y., Thomson, M. (eds), Current Technologies in Plant Molecular Breeding, 15-50. Springer, Dordrecht.

Zietkiewicz, E., Rafalski, A., Labuda, D., 1994: Genome finger printing by simple sequence repeat (SSR) anchored polymerase chain reaction amplification. Genomics 20, 176-183. 